УДК 78.06+78.085
DOI https://doi.org/10.31723/2524-0447-2020-30-2-22

Володимир Петрович Клещуков

ORCID: 0000-0002-6559-3877

здобувач кафедри історії музики та музичної етнографії

Одеської національної музичної академії імені А. В. Нежданової

kvp.rabota70@gmail.com

\title{
СЕМІОЛОГІЧНІ АСПЕКТИ МУЗИЧНОГО ТА ХОРЕОГРАФІЧНОГО МИСТЕЦТВ: ДО ПРОБЛЕМИ ВЗАЕМОДІї
}

Мета роботи. У статті виявляються принципи функціонування візуально-просторових та семіотичних аспектів музичного і хореографічного мистецтв у їх взаємодії. Методологія дослідження полягає в застосуванні компаративного, естетико-культурологічного, історичного методів, а також системного, синергетичного, музикознавчих та музично-виконавських підходів. Наукова новизна роботи полягає в поглибленні уявлень про взаємозалежне та специфічне функціонування зорово-просторових, пластичних, знаково-комунікативних факторів вказаних двох видів мистецтв - музичного і танцювального. Аналізуються їх прояви і специфіка у виконанні і сприйнятті музики, їх зв'язок з іншими музично-виразовими засобами, а також їх місце і роль у процесі виконавського мислення. Висновки. Тривалий розвиток різноманітних взаємовпливових відносин музики і танцю - від синкретизму до автономії та нових форм, спонукає й до нового міждисциплінарного підходу до досліджень. Спільні параметри буття двох мистецтв (знаково-комунікативний характер, невербальність вираження, розгортання художнього образу у часі, метро-ритмічний складник, просторовість із здатністю до візуальної інтерпретації музичної образності, пластичність, суб'єктивний, індивідуальний характер сприйняття образності) утворюють іманентні умови для їх взаємовпливу i поєднання, що у XX столітті посилилось через актуалізацію позамузичних засобів у музиці. Постійний вплив різних танцювальних жанрів на «чисту» музику сприяв виникненню поняття «танцювальності» як специфічної форми музичної жанровості та як узагальненої семантики руху в музиці. Подібна синестезія стала плідною для обох видів мистецтва. Для музики вона ознаменувалася збагаченням ї̈ візуальними параметрами, розвитком музичної моторики, емансипацією інструментальної музики, формуванням інструментальних жсанрів та стилів.

Ключові слова: музика, танець, взаємодія, семіотичні властивості, пластичність, просторовість, візуалізація, танцювальність, музична моторність.

(C) Клешуков В. П., 2020 
Kleshchukov Volodymyr Petrovych, Applicant at the Department of Music History and Music Ethnography of the Odessa National A. V. Nezhdanova Academy of Music

Semiological aspects of musical and choreographic arts: towards the problem of interaction

Objective. The article reveals the principles of the functioning of the visual-spatial and semiotic aspects of the musical and choreographic arts in their interaction. The research methodology consists in the use of comparative, aesthetic-cultural, historical methods, as well as systematic, synergetic, musicological and music-performing approaches. The scientific novelty of the work lies in the deepening of ideas about the interrelated and specific functioning of the visual-spatial, plastic, sign-communicative factors of these two types of arts - music and dance. Their manifestations and specificity in the performance and perception of music, their connection with other musical expressive means, as well as their place and role in the process of executive thinking are analyzed. Conclusions. The continued development of various interacting relationships of music and dance, from syncretism to autonomy and new forms, prompts a new interdisciplinary approach to research. The joint parameters of the existence of the two arts (sign-communicative character, non-verbal expression, the deployment of an artistic image in time, metrorhythmic component, spatiality with the ability to visually interpret musical imagery, plasticity, subjective, individual character of perception of imagery) form immanent conditions for their mutual influence and combinations, which intensified in the twentieth century due to the actualization of extra-musical means of rotation in music. The constant influence of various dance genres on "pure" music contributed to the emergence of the concept of "danceability" as a specific form of musical genre and as a generalized semantics of movement in music. This synesthesia has been fruitful for both arts. For music, it was marked by the enrichment of its visual parameters, the development of musical motor skills, the emancipation of instrumental music, the formation of instrumental genres and styles.

Key words: music, dance, interaction, semiotic properties, plasticity, spatiality, visualization, danceability, musical quickness.

Клешуков Владимир Петрович, соискатель кафедры истории музыки и музыкальной этнографии Одесской национальной музыкальной академии имени А. В. Неждановой.

Семиологические аспекты музыкального и хореографического искусств: к проблеме взаимодействия.

Цель работы. В статье выявляются принципы функционирования визуально-пространственных и семиотических аспектов музыкального и хореографического искусств в их взаимодействии. Методология исследования заключается в применении компаративного, эстетико-культурологического, исторического методов, а также системного, синергетического, музыковедческих и музыкально-исполнительских подходов. Научная новизна работы заключается в углублении представлений о взаимосвязанном и специфическом функционировании зрительно-про- 
странственных, пластических, знаково-коммуникативных факторов указанных двух видов искусств - музыкального и танцевального. Анализируются их проявления и специфика в исполнении и восприятии музыки, их связь с другими музыкально-выразительными средствами, а также их место и роль в процессе исполнительного мышления. Выводы. Продолхительное развитие различных взаимодействующих отношений музыки и таниа - от синкретизма к автономии и новым формам, побуждает и к новому междисииплинарному подходу к исследованию. Совместные параметры бытия двух искусств (знаково-коммуникативный характер, невербальность выражения, развертывание художественного образа во времени, метро-ритмическая составляющая, пространственность со способностью к визуальной интерпретации музыкальной образности, пластичность, субъективный, индивидуальный характер восприятия образности) образуют имманентные условия для их взаимовлияния и сочетания, что в $Х Х$ веке усилилось ввиду актуализации внемузыкальных средств выражения в музыке. Постоянное воздействие различных танцевальных жканров на «чистую» музыку способствовало возникновению понятия «танцевальности» как специфической формы музыкальной жанровости и как обобщенной семантики движения в музыке. Подобная синестезия стала плодотворной для обоих видов искусства. Для музыки она ознаменовалась обогащением ее визуальными параметрами, развитием музыкальной моторики, эмансипацией инструментальной музыки, формированием инструментальных жсанров и стилей.

Ключевые слова: музыка, танеи, взаимодействие, семиотические свойства, пластичность, пространственность, визуализация, танцевальность, музыкальная расторопность.

Актуальність теми дослідження. 3 найдавніших часів розвитку людства універсальним засобом впливу на людські емоції вважалися звук і зорова (тактильна) просторовість. Саме ці параметри впливу мають виражений знаково-комунікативний характер і є спільними для музики і танцю. Так, сучасні дослідники вказують, що «музичні звучання, у сенсі «вмикачів» предметних та емоційних асоціацій, є близькими до мовних, а організація музичного твору багато в чому схожа 3 організацією мовного висловлювання, але з іншим поєднанням ірраціональних властивостей по відношенню до раціональних» [3, с. 331]. Про зв'язки музичної і мовної інтонації постійно говорять музикознавці і виконавці. 3 іншого боку, результати досліджень фізіології вищої нервової діяльності (як і дані історії культури) вказують, що безпосередньо символічними формами, які на несвідомому рівні репрезентують культурно значимий зміст, $\epsilon$, поряд зі звуком, просторова 
визначеність - пластичність, об’ємність, тяжкість / легкість тощо. Навіть більше, сама звукова матерія (і навіть окремий звук) володіють просторовими визначеннями. Саме конкретні чуттєві сприйняття мають потенційну впливово-символічну енергію: несвідомі переживання діють безпосередньо і отримують незліченну кількість текстових експлікацій (художніх, філософських, езотеричних тощо). Серед вказаних безпосередніх чуттєвих сприймань найбільш значимі візуальні, адже «зір є сенсорною системою, яка дає людині найбільш велику і багату відтінками інформацію», тому, «якщо по різних сенсорних каналах надходить суперечлива інформація, то зазвичай віддається перевага зоровій інформації» [13, с. 273]. Стосовно витоків європейської культури візуальна, оптична природа сприйняття вважається очевидною [21, с. 57] і є свідченням іiі раціоналізованих тенденцій, що знайшло відображення не тільки у пластичних мистецтвах і музиці, а й у міфологічних уявленнях і в повсякденній понятійній системі, яка $є$ метафоричною за своєю суттю [6]. Втім, стосовно культури архаїки слід говорити про значущість не стільки візуального, скільки тактильного сприйняття - важливого як у музичному (зокрема, інструментальному), так і у хореографічному мистецтвах. Отже, дослідження візуально-просторових та семіотичних аспектів вказаних видів мистецтва $є$ актуальним зрізом наукового дослідження.

Тому метою статті є виявлення візуально-просторових та семіотичних аспектів музичного і хореографічного мистецтв у їх взаємодії.

Виклад основного матеріалу. Аналізуючи еволюцію власне естетичного у давньогрецькій культурі, В. Татаркевич зазначає, що античні вчені підходили до розуміння сприйняття як до різновиду дослідження, «огляду», розуміючи мислення як дешо «споріднене сприйняттю» [20]. Людське мислення, будучи «взаємозв'язком інтенсіональних сутностей», не «споглядається», і стає «фактом ментального простору» (соціального і інтерсуб'єктівного) лише за допомогою природної мови (або іншої знакової системи) [12, с. 62]. За багатовікову історію музичне мистецтво сформувало унікальну систему художньо-виразових засобів, зокрема танцювальні жанрові ознаки увійшли до музичного (передусім інструментального, але не тільки) мистецтва як важливий вектор розвитку власне музичних форм - музичної просторовості, фактури, музич- 
ної моторики, метро-ритмічної системи тощо, а виникнення i розвиток музичного інструментарію напряму пов'язані 3 ритуальною, трудовою і дозвільною символікою, а також 3 танцювальністю. Завдяки вказаній системі музика стала здатною відображати різноманітні сторони як особистісних, узагальнено-філософських або художньо-естетично спрямованих явищ, так і предметного або живого світу навколишньої дійсності, зображальності. Ця система засобів знаходиться в постійному русі, як і взаємодія музичного та хореографічного начал, спільних і специфічних знаково-комунікативних властивостей у ній. Процес еволюції художньо-виражальних засобів, на думку Д. Варламова, демонструє тенденції десинкретизації музичного мислення, мови і творчості [2]. Безперервна еволюція музичної мови і мовлення приводять до зміни виразових елементів, народження нових їх видів.

Сучасні теорії в сфері психології і фізіології людини грунтуються на позиції про будь-який живий організм як «сукупність безлічі злагоджено взаємодіючих функціональних систем», тому «за рахунок інформації, постійно циркулюючої як усередині окремих саморегульованих функціональних систем (як, наприклад, музика та танець - В.К.), між ними, а також між функціональними системами живих організмів і навколишнього середовища, створюють тісно взаємодіючі внутрішні і зовнішні інформаційні поля живих організмів» [3, с. 484]. Так, за результатами акустичних експериментів, вчені доходять висновку, що «розробка методів акустичної неусвідомлюваної сугестії» стає можливою через використання «просторових і фазових акустичних характеристик (насиченість голосу по обертонам, діапазони частотних показників ... і так далі)» [13, с. 272]. Інші просторові характеристики «спрацьовують» у моторних або повільно-кантиленних рухових асоціаціях в музиці. Такі пластичні засади багато в чому визначають взаємовпливи музики і танцю.

К. Леві-Стросс вказує на пряму залежність між пластикою людини і характером іiі мислення [5]. Отже, мислення на музичному інструменті або у співі завжди проявляється у тому числі й на пластичному рівні. «По рухах може бути складена історія “людини громадської", людини в іiі взаєминах із зовнішнім світом і в кінцевому рахунку - з самою собою. Адже пластика - це не тільки існування тіла в просторі, але також і буття душі, малюнок руху і візерунок слова одно- 
часно. Пластична думка, пластичне вираження звуку, фарби або слова є так само зображальними і протистоять хаосу, як і людська хода, жестикуляція, рухи тіла» [22]. Відчуття пластичності підсвідомо народжується вже на ранніх стадіях розвитку культури. Адже людина завжди прагнула жити в злагоді, гармонії з природою, з навколишнім світом. Тому пластичність має виражену тенденцію до історичної еволюції своїх форм, визначаючи домінанти різних епох і періодів людського розвитку, національно-ментальних традицій тощо. Саме тому музичне мистецтво, яке націлене на всеохоплююче поєднання минулого-теперішнього-майбутнього, завжди буде дотичним до пластичності (звуковидобування, фразування, контрастів, вираження). Тому й його синкретичний зв'язок з танцювальною пластичністю певним чином зберігається навіть під час десинкретизації мистецтв. Адже символи архаїчної культури «синкретичні не тільки структурно або функціонально, але і семантично (з чим пов'язана і збережена на наступних етапах їх «полісемантичність» або амбівалентність), представляючи собою предмет афектованого сприйняття і поведінки» [21, с. 62]. Недаремно В. Мейерхольд у статті про постановку вагнерівської опери «Тристан та Ізольда» проголошує: «Людина разом з согармонічною обстановкою і соритмічною музикою являють собою вже витвір мистецтва. У чому ж тіло людське, гнучке для служіння сцені, гнучке в своїй виразності, досягає вищого свого розвитку? У танці... Там, де слово втрачає силу виразності, починається мова танцю (те саме можна віднести й до музики - В.К.). В давньояпонському театрі на так званій “Но”-сцені, де розігрувалися п'єси на зразок наших опер, актор обов'язково був разом з тим і танцівником» [9]. I далі режисер підтверджує свій висновок словами Р. Вагнера: «Музичне і поетичне мистецтва стають зрозумілими ... лише через танцювальне мистецтво» [там само]. Але слова про граничність слова можна повною мірою віднести й до музичного мистецтва - воно також розпочалося (у шляху своєї автономізації, десинкретизації) там, де «слово втрачає силу виразності».

Отже, хореографічне мистецтво, як і музичне, має знаково-комунікативний характер, причому художні знаки в танці організовуються за законами, схожими з музичними - метроритму, гармонії, контрасту, консонансів, дисонансів, архітектоніки, форми тощо. Ці художні знаки Д. Махліна поділяє 
на три групи: художні зображення (аналогічні іконічним знакам поза мистецтвом), засоби експресії або виразові прийоми і символічні засоби [7, с. 372-374]. Таким чином, виокремлюються три основні властивості художньої форми - зображальність, виразовість і умовна знаковість. До усіх трьох по-своєму стають дотичними як музика, так і танець. Новий синтез музично-хореографічної єдності являє балет, а також нові жанри «симфонічного балету» та «хореографічної симфонії». При цьому танцювальна композиція - іiі характер, темп, метр, ритм - спирається на музичне викладення. Саме музика дає хореографічній пластиці ритмічну основу, вона визначає іiі емоційний склад, характер, образну виразовість. Про музику справедливо кажуть, що вона є душею танцю. Ж. Новер вказував: «Танець подібний до музики, а танцівники - до музикантів ... У нас теж є і октави, і цілі, і половинні, і чверті, і шістнадцяті, тридцять і другі, і шістдесят четверті. Нам теж доводиться відраховувати такти і дотримуватися розміру; з'єднані всі разом, це невелика кількість па і невелика кількість нот відкривають шлях до безлічі різних сполучень і пасажів. Смак і талант завжди знайдуть джерело новизни, на тисячі різних ладів і тисячі різних способів переставляючи і комбінуючи цей невеликий запас нот і па. Ось ці-то па - повільні і витримані, жваві й стрімкі, і є джерелами безперервної різноманітності» [10, с. 238-239].

Музична образність (як і танцювальна) має досить абстрактний характер і тому передбачає множинну варіантність композиторських, виконавських і слухацьких трактувань. Ще одна важлива риса музичного образу - його динамічний характер. Як і хореографічний образ, музичний розгортається у часі, розкриваючи свої властивості в послідовному саморозвитку або співставлені (зіткнені) з іншими образами. Тому обидва вони виникають «тут і зараз» і залишаються тільки в нашій пам'яті, тому важливим виконавським і композиторським завданням є динаміка, енергетично-емоційна логіка розгортання. Тому сприйняття образів музики і хореографії має в значній мірі суб'єктивний, індивідуальний характер, ніж сприйняття образів живопису, літератури і театру, які завжди більш конкретні.

Найбільш ефективний, прямий спосіб занурення в світ почуттів, які висловлюються музикою і хореографією, пов'язані з ними рухи, які у танці відбиваються безпосеред- 
ньо (стаючи його мовою), а у музиці - опосередковано та технічно-безпосердньо. Слухаючи і сприймаючи музику в русі, людина проживає музичні образи пластично, відчуває i діє незвичайним для себе способом, що виходять за рамки рухів в повсякденному житті. Таке «життя в образі» накладає відбиток і на характер рухів. Це позначається на більш «делікатних» властивостях, ніж просто швидкість, точність, економність. Під впливом музичного образу рухи (у тому числі танцювальні) стають характерними, несуть знаки того чи іншого почуття.

Механізм цього явища полягає у тому, що контроль рухів почуттям $\epsilon$ найважливішим моментом психіки людини: «Будь-яка зміна в положенні тіла, ніг і тулуба, так само як і будь-який рух цих частин, дають нашій свідомості, за посередництва так званого м'язового почуття, німі, але настільки певні чуттєві знаки, що ми негайно ж дізнаємося за ними ту страшну зміну ... Певній низці рухів завжди відповідає у свідомості певна низка чуттєвих знаків; якщо ж рухова низка повторюється багато разів, то разом з рухом заучуються і відповідні чуттєві знаки. Закарбовуючись у пам'яті, вони утворюють низку нот, за якими або, точніше кажучи, під контролем яких розігрується відповідна рухова п’єса» [16, с. 387]. М'язове почуття, відповідне різному характеру рухів, допомагає людині в процесі пластичного моделювання музики зробити вибір різних дій, які забезпечують рішення художнього завдання.

Зрозуміти сутність музики, закони іiі функціонування та розвитку можна тільки розглядаючи іiі в системі «мов людського спілкування». Б. Асаф'єв проголосив думку про те, що музичне інтонування - це образно-звукове відображення дійсності, аналогічно якому поетична, мальовнича, архітектурна, хореографічна та інші мови - це діяльність людського інтелекту, особливий процес виявлення людської свідомості [1]. У цьому аспекті мови мистецтва, зокрема музична, виступають повноцінними мовними, знаково-семіотичними системами. Сучасна нейрофізіологія доводить, що мові передує невербальне формування думки у правій півкулі мозку - у звуковій та руховій жестово-мімічній формах. «Те, що звукова інтонація, жест і міміка «керуються» 3 одного центру (права півкуля) є важливим моментом їхньої спільності, єдиної природи, і служить суттєвим аргументом для їх теоретич- 
ного зближення. Сучасна психологія, розглядаючи проблеми виникнення відчуття, сприйняття та психіки людини, єднає їх з проблемою походження руху, дії взагалі» [19, с. 29].

В. Медушевський наполягає на такій властивості правопівкульового мислення, як «інтимний зв'язок всіх його знакових систем», завдяки якому музика набуває можливості узагальнити не лише свій власний досвід, але й досвід всієї культури: «у звуках музики відображені екстаз ритуального танцю, чемні жести галантної епохи, розміреність військової ходи, неозоре різноманіття мовної виразності» [8, с. 43] (усі ці рухові знаки опрацьовує і танець). Власне, такі рухові відчуття викликали, на наш погляд, необхідність у створенні музичного інструментарію: «якщо вокальна музика в ряді випадків будується на відтворенні звучання людської мови, то музика інструментальна, яка безпосередньо не пов'язана з вербальною мовою, має інші корені - не зображення (зображення специфічними музичними засобами - на нашу думку, у тому числі - В.К.), а відбиття духовних процесів людини, яке виражається у русі інтонованих звуків» [19, с. 31]. С. Скребков вказує на три корінних жанрових типи музичного тематизму (кантилена/спів, танцювальність, декламаційність як різні боки музичного інтонування), з яких два останні є «історично первинними: танцювальність (точніше моторність, включаючи усі види танцю, маршу, передані музикою трудові рухи) і декламаційність (вигуки, заклики, голосіння, речитація і так далі)», а перший - «аріозний розспів, кантилена - виникає у музиці... на основі тих двох і формується в міру досягнення музичним мистецтвом своєї художньої самостійності, незалежно від слова і танцю» [17, с. 17]. О. Самойленко визначає відповідні цим жанровим типам «три опорних начала як вищі, граничні, «заповітні» смислові інстанції - Пам'ять, Гра, Любов, які «відповідають сакральному, когнітивному і особистісному - «людяному» - началам культури» [14].

Танцювальна музика, з одного боку, органічно увійшла до музичного побуту (дозвілля), вбираючи загальні моторно-інтонаційні (метро-ритмічні та мелодійні, гармонічні) знаки того чи іншого народно-танцювального жанру, без «претензій» на індивідуальну неповторність (первині жанри); з іншого боку, трансформувалася в музичному інструменталізмі на «вторинні жанри», в яких повною мірою проявляється винахідливість та індивідуальність авторів. О. Селицький справедливо вва- 
жає, що «без таких “побутових ін'єкцій” музика академічної традиції рідко може розраховувати на довголіття і слухацьку увагу» [15, с. 21]. Фактично танцювальна сфера постала «найбільш визначеним та типовим провідником моторності від первинних основ музики до індивідуальної композиторської творчості. Отже, танець і танцювальність - це одна з посередніх ланок між моторністю, як вираженням людини в русі, та можливостями іï вираження в музиці, тобто через танцювальність музика освоює моторність» [19, с. 71]. Інший шлях опрацювання моторності в академічній музиці - моторно-імпровізаційні структури (на вокальні і танцювальні теми) безпосередньо на площині (гриф, клавіатура, корпус духових) музичного інструменту, які вельми опосередковано або взагалі не пов'язані з танцювальністю (як, наприклад, загальні форми руху і музичному інструменталізмі). В цьому разі вже музична структура може стати основою для хореографічно-візуального втілення, як це відбувається в балетах або, пізніше, так званих «балетних симфоніях».

Музика танцювальних первинних та вторинних жанрів організовується за принципами пластичності (яка охоплює весь художній комплекс, пов'язаний з образами людського, природного та мисленнєво-емоційного руху). На думку Т. Куришевої, такий тип руху може бути ординарним (знайомим) і специфічним. «За першим стоїть конкретна образна сфера, до якої веде танець або ритуально-обрядове дійство. Специфічні типи руху, навпаки, не викликають прямих асоціацій. За допомогою утвореного пластичного образу вони спроможні втілювати різні емоційні стани» [4, с. 28]. О. Суббота пропонує для визначення цих двох різновидів пластичного типу музичної моторності поняття «загальні форми руху» (з характерною загально-впорядкованою ритмікою) та «танцювальність» (іманентно-впорядкована ритміка) [19, с. 122] і виявляє такі групи (види) танцювальності як типу музичної моторності: декларована (конкретно-жанрові танцювальні п'єси - мазурки, полонези, вальси, польки і так далі; твори з узагальнено-жанровою танцювальністю, наприклад, «Угорські танці» А. Дворжака, «Симфонічні танці» С. Рахманінова; твори з комбінованою - поліжанровою - танцювальністю), недекларована («знята танцювальність», яка присутня в творах завдяки індивідуально-впорядкованій ритміці, але не «заявлена» композитором і дає 
підставу для появи таких понять як «мазурочність», «вальсовість» та ін.) та балетна (сутність якої полягає у взаємообумовленості музики і людського руху як явищ, перш за все, процесуальних). Т. Куришева справедливо вказує, що саме балет в найчистішому виді демонструє здатність до візуальної інтерпретації музичної образності.

Танцювально-моторні властивості їх чітким структуруванням багато в чому сприяли автономізації музичного інструменталізму 3 формуванням самостійних інструментальних жанрів, а також клавірного, лютневого, оркестрового і т.п. інструментальних стилів. У цьому сенсі цікавими є твердження I. Стравінського про те, що музика XVIII століття інструментальна чи вокальна, духовна чи світська - вся $є$ у деякому сенсі танцювальною, а також докір композитора під час виконання симфонії В.А. Моцарта - диригенту, який «постійно просив оркестр “співати" і ніколи не нагадував йому, що треба танцювати» [18, с. 172]. Дійсно, симфонічні жанри доби класицизму, де танцювальні засоби не тільки виявляли структурно-організуючі функції, а й змогли зіставлятися 3 кантиленними за типом контрасту чи доповнення, навряд чи би сталися. Цікаво, що Г. Гендель вважав інструментальну мелодію свого роду танцем, рухи якого позбавлені наочності (у «знятій формі» за О. Субботою). Однак ці рухи «присутні ідеально у свідомості - у виді моторних асоціацій, виникнення яких «запрограмовано» композитором завдяки використанню певних засобів і прийомів музичної моторності» [19, с. 125].

Узагальнена танцювальність в музиці зумовлює висунення в якості провідних формотворчих принципів метроритмічну регулярність, танцювальну остинатність, симетричність синтаксичних i композиційних структур, артикуляційно-ритмічну формальність, посилення значущості ігрової логіки. Подібні принципи відсторонюють певним чином логіку епічного музичного «оповідання», проте виступають як основні у симфонії доби класицизму. Так, у розробках симфоній Гайдна, зокрема «Лондонських», активно використовується мотивний тип розвитку, що зумовлене танцювальним характером тем, де величезну роль відіграє ритм. Адже танцювальні теми легше поділяються на окремі мотиви, ніж кантиленні (власне, з такої структуризації, зокрема, розпочався процес автономізації музичного мистецтва та його інструментального 
напряму). Для розвитку Гайдн обирає найбільш яскравий i запам'ятовуваний мотив теми, і не обов'язково початковий, як наприклад, це відбувається в розробці першої частини 104-ої симфонії, де розробляється мотив 3-4 тактів головної теми, як найбільш здатний до змін: варіантність трансформацій його характеру (Гайдн тут проявляє невичерпну винахідливість) простягається від запитально-невпевнених до грізно або стверджуюче-наполегливих звучань.

Висновки. Тривалий розвиток різноманітних взаємовпливових відносин музики і танцю, від синкретизму до автономії та нових форм спонукає й до нового міждисциплінарного підходу до досліджень. Спільні параметри буття двох мистецтв (знаково-комунікативний характер, невербальність вираження, розгортання художнього образу у часі, метро-ритмічний складник, просторовість із здатністю до візуальної інтерпретації музичної образності, пластичність, суб'єктивний, індивідуальний характер сприйняття образності) утворюють іманентні умови для їх взаємовпливу і поєднання, що у XX столітті посилилось через актуалізацію позамузичних засобів у музиці.

Постійний вплив різних танцювальних жанрів на «чисту» музику сприяв виникненню поняття «танцювальності» як специфічної форми музичної жанровості та як узагальненої семантики руху в музиці. Подібна синестезія стала плідною для обох видів мистецтва. Для музики вона ознаменувалася збагаченням іiї візуальними параметрами, розвитком музичної моторики, емансипацією інструментальної музики, формуванням інструментальних жанрів та стилів.

\section{СПИСОК ЛІТЕРАТУРИ:}

1. Асафьев Б. Музыкальная форма как процесс. Кн. 1, 2. Изд. 2-е. Ленинград : Музыка, 1971. 373 с.

2. Варламов Д.И. Онтология искусства: избранные статьи 2000-2010 гг. Москва : Композитор, 2011. 316 с.

3. Гуменюк В.А., Судаков К.В. Воздействие на человека динамической цветомузыки. Энергоинформационные поля функциональных систем. Под ред. К.В. Судакова. Москва, 2001. С. 313-331.

4. Курышева Т.А. Театральность и музыка. Москва : Советский композитор, 1984. 199 с.

5. Леви-Стросс К. Структурная антропология; пер. с фр. В. В. Иванова. Москва : ЭКСМО, 2001. 512 с.

6. Лосев А.Ф. Очерки античного символизма и мифологии. Москва : Мысль, 1993. 960 с. 
7. Махлина С.Т. Словарь по семиотике культуры. Санкт-Петербург : Искусство, 2009. 752 с.

8. Медушевский В.В. Человек в зеркале интонационной формы. URL: https://mus.academy/storage/magazine/articles/pdfs/compressed/ PRLB1wLczNs1fehollC5VgnKKB1fnipeXWo8yhpR.pdf.

9. Мейерхольд. В.Э. К постановке «Тристана и Изольды» в Мариинском театре 30 октября 1909 года. URL: http://wagner.su/ node/1112 (дата звернення 29.06.2020р.)

10. Новер Ж.Ж. Письма о танце и балетах; ред. и вступ. статья, Ю.И. Слонимского. Лениград ; Москва : Искусство, 1965. 375 с.

11. Рыбкина Т.В. Музыкальное восприятие: пластические образы ритмо-интонации в свете учения Б. Асафьева : дис. ... канд. Искусствоведения : 17.00.02 / Рос. акад. муз. им. Гнесиных. Москва, 2005. $179 \mathrm{c}$.

12. Рябцева Н.К. Мысль как действие или риторика рассуждения. Логический анализ языка. Модели действия. Москва : Наука, 1992. С. 60-69.

13. Савин А.Ю., Прокофьев В.Ф. Психологические аспекты сверхслабых энергоинформационных воздействий. Информационно-суггестивные методы воздействия на сознание человека. Энергоинформационные поля функциональных систем / Под ред. К.В. Судакова. Москва, 2001. С. 260-296.

14. Самойленко А.И. Лекции по музыкальной семиологии. Тема 1. Смысл и понимание: подходы и теории. Имманентный логос музыки и определения музыкального смысла. URL: http:// musikology.com.ua/upload-files/semiology/Tema_1.pdf.

15. Селицкий А. Парадоксы бытовой музыки. Музыка быта в прошлом и настоящем. Ростов-на-Дону : Изд-во Ростовского государственного педагогического университета, 1996. С. 19-35.

16. Сеченов И. Рефлексы головного мозга. И. Сеченов. Избранные философские и психологические произведения. Москва, 1947. 473 с.

17. Скребков С.С. Художественные принципы музыкальных стилей Москва : Музыка, 1973. 446 с.

18. Стравинский И. Диалоги. Воспоминания. Размышления. Ленинград : Музыка, 1971. 416 с.

19. Суббота О.В. Музична моторність як категорія музикознавства : дис... канд. мистецтв : 17.00.03 / Одесь. держ. муз. акад. імені А.В. Нежданової. Одеса, 2005. 197 с.

20. Татаркевич В. Античная эстетика. Москва: Искусство, 1977. $327 \mathrm{c}$.

21. Фадеева И.Е. Теория и культурно-историческая феноменология символа : дис. ... д-ра культурол. Наук : 24.00.01 / Рос. гос. пед. ун-т шимени А.И. Герцена. СПб., 2004. 413 с.

22. Фортунатова В.А. Человек в мире культуры : учеб. пособие. Н. Новгород : НГПУ, 1998. 98 с. 


\section{REFERENCES}

1. Asafiev, B. (1971) Musical form as a process. Book 1-2. Leningrad :Music. [in Russian].

2. Varlamov, D.I. (2011). Ontology of Art: Selected Articles 2000-2010 M.: Composer [in Russian].

3. Gumenyuk, V.A., Sudakov K.V. (2001). Impact of dynamic color music on a person. Energy information fields of functional systems. Moscow. (pp. 313 - 331) [in Russian].

4. Kurysheva, T.A. (1984). Theatricality and music. M.: Soviet composer. [in Russian].

5. Levi-Strauss, K. (2001). Structural Anthropology. M.: EKSMO. [in Russian].

6. Losev, A.F. (1993). Essays on ancient symbolism and mythology. M.: Thought. [in Russian].

7. Makhlina, S. T. (2009). Dictionary of the semiotics of culture. $\mathrm{SPb} .:$ Art.. [in Russian].

8. Medushevsky, V.V. (2020). Man in the mirror of intonation form. URL: https://mus.academy/storage/magazine/articles/pdfs/compressed/ PRLB1wLczNs1fehollC5VgnKKB1fnipeXWo8yhpR.pdf

9. Meyerhold., V.E. (2020). For the production of Tristan and Isolde at the Mariinsky Theater on 30 October 1909. URL: http://wagner.su/ node/1112

10. Nover, J. J. (1965). Letters about dance and ballets. L.; M.: Art. [in Russian].

11. Rybkina, T.V. (2005). Musical perception: plastic images of rhythm-intonation in the light of B. Asafiev's teachings:. Candidate's thesisMoscow: / Ros. acad. muses. them. Gnesins [in Russian].

12. Ryabtseva, N.K. (1992). Thought as action or rhetoric of reasoning. Logical analysis of language. Action models. M.: Science (pp. 60-69). [in Russian].

13. Savin, A.Yu., Prokofiev, V.F. (2001). Psychological aspects of superweak energy-informational influences. Information-suggestive methods of influencing human consciousness. Energy information fields of functional systems Moscow. (pp. 260-296.). [in Russian].

14. Samoilenko, A.I. (2014). Lectures on musical semiology. Topic 1. Meaning and understanding: approaches and theories. The immanent logos of music and definitions of musical meaning. URL: http://musikology. com.ua/upload-files/semiology/Tema_1.pdf [in Russian].

15. Selitsky, A. (1996). The paradoxes of everyday music. Music of everyday life in the past and present. Rostov-on-Don: Publishing house of the Rostov State Pedagogical University (pp. 19-35). [in Russian].

16. Sechenov, I. (1947). Reflexes of the brain. Selected philosophical and psychological works. Moscow [in Russian].

17. Skrebkov, S.S. (1973). Artistic principles of musical styles Moscow: Music, [in Russian].

18. Stravinsky, I. (1971). Dialogues. Memories. Reflections. Leningrad: Music [in Russian]. 
19. Sиввоta, O.W. (2005). Musical motor skills as a category of musicology. Candidate's thesis. Odessa / Odessa. state music. acad. named after A.V. Nezhdanova [in Ukrainian].

20. Tatarkevich, V. (1977). Ancient aesthetics. Moscow: Art [in Russian].

21. Fadeeva, I.E. (2004). Theory and cultural-historical phenomenology of the symbol. Doctor's thesis. SPb / Ros. state ped. University of Shimeni AI Herzen [in Russian].

22. Fortunatova, V.A. (1998). Man in the world of culture: textbook. allowance. N. Novgorod: NGPU. [in Russian].

УДК 78.452

DOI https://doi.org/10.31723/2524-0447-2020-30-2-23

Лариса Петрівна Мухіна

ORCID: 0000-0002-2381-7297

acniрант

Сумського державного педагогічного університету

імені А. С. Макаренка

Lorele_a@ukr.net

\section{ВИКОНАВСЬКИЙ КОНЦЕПТ СОЛОМІЇ КРУШЕЛЬНИЦЬКОЇ В ІТАЛІЙСЬКІЙ ТА НІМЕЦЬКІЙ ОПЕРІ КІНЦЯ ХІХ - ПОЧАТКУ ХХ СТОЛІТЬ}

Соломія Крушельницька є видатною примадонною світовою оперної сцени кін. XIX - поч. XX ст. Ï̈ творчість вплинула на розвиток українського оперного мистецтва, залишаючись невід'ємною частиною світової оперної культурної спадщини. Мета роботи - виявлення особливостей оперно-виконавської діяльності Соломії Крушельницької, яка є унікальною щодо своєї творчої майстерності. Методологія дослідження. Обгрунтовано аналітичне поняття «виконавський концепт», яке узагальнюе характерні риси виконавчої техніки та артистичного стилю співачки в контексті постановки конкретного художнього твору. Виконавський концепт включає характеристику творчого методу

(C) Мухіна Л. П., 2020 